\title{
CONBRADIR
}

\section{DIREITO E FORÇA: BREVES CONSIDERAÇÕES ACERCA DA CONEXÃO (NÃO)NECESSÁRIA ENTRE DIREITO E COERÇÃO EM FREDERICK SCHAUER.}

Congresso Brasileiro Online de Direito, 1ạ edição, de 11/10/2021 a 13/10/2021

ISBN dos Anais: 978-65-89908-73-9

FELIPE; Bruno Farage da Costa 1, HARA; Johnny Marcelo 2, JESUS; Renata Menezes de 3, MEDINA; Lízia Coelho ${ }^{4}$, BASTOS; Danuza da Silva Crespo ${ }^{5}$

\section{RESUMO}

Em "O conceito de direito", H.L.A Hart traz uma reflexão que acaba servindo de base para a criação da figura do puzzled man (ou homem perplexo), muito refletida nos debates jusfilosóficos acerca da conexão entre direito e coerção. A ideia do puzzled man construída por Hart tem relação direta com algumas premissas de sua teoria do direito: o "homem perplexo" indica que muitas pessoas obedecem às leis mesmo sem estarem preocupadas com a sanções advindas de seu descumprimento. Contudo, será que realmente podemos afirmar que o uso da força é dispensável na delimitação da natureza do direito? Uma obra mais recente, do autor Frederick Schauer - The Force of Law - lança novas bases para a reflexão dessa premissa. O presente artigo esboça uma revisão, com pesquisa bibliográfica, cujo objetivo não é realizar uma crítica à Schauer com argumentos pós-positivistas, mas sim demonstrar a complexidade dos argumentos trazidos em The force of law e como, na maioria dos casos, são argumentos acertados. Uma das grandes contribuições do autor, a meu ver, reside na exploração de uma perspectiva até então utilizada como argumento, mas sem profundidade, a partir da figura do puzzled man. Se muitas pessoas obedecem às regras, pelo simples fato de serem regras, por que isso acontece? Em linhas gerais, Schauer defende a hipótese de que é possível explicar o direito a partir do seu viés coercitivo, mas reduzi-lo a esse elemento seria um erro. Assim, Schauer defende que a coerção, um aspecto tão central para autores como Bentham e Austin, surge como elemento contingente e não necessário, sendo "útil, mas não essencial, ubíqua, mas não universal" e, portanto, não faz parte da própria natureza do direito. Partindo do pressuposto de que a coerção é uma característica presente no direito, mas não essencial para a afirmação de sua natureza, a preocupação de Schauer passa a residir na explicação dos fatores que fazem as pessoas a internalizarem as regras de direito e a obedecê-las. Segundo o autor, existem diversas razões pelas quais alguém respeita o direito, mas não por medo da sanção. Dentre elas temos duas marcantes: l) por questões preferenciais; II) por um misto de racionalidade e moralidade. Em suma: o direito não se explica somente pelo viés coercitivo, mas dar menor relevância ou excluir a participação desse conceito na definição de "o que é direito", não seria condizente com a realidade.

PALAVRAS-CHAVE: DIREITO E COERÇÃO, HOMEM PERPLEXO, DIREITO E FORÇA 
